\title{
Investigating the effect of testosterone supplement on heart and muscle damage in rats applied with swimming exercise
}

\author{
Ömer KULAKSIZ, Sefa LÖK ${ }^{1}$ \\ ${ }^{1}$ Selcuk Universty, Faculty of Sport Science, Konya, Turkey \\ Address Correspondence to S, Lok, e-mail: sefalok@selcuk.edu.tr
}

\begin{abstract}
Anabolic Androgenic Steroids which are a synthetic derivative of testosterone are known to be used by some sportsmen in order to improve performance. The present study was conducted to investigate the effect of testosterone supplement on heart and muscle damage in rats applied with swimming exercise. The study was conducted on 30 day-old 27 (Wistar, male) rats that were supplied from "Selçuk University Experimental Medicine Research and Application Center". The rats were divided into 4 groups. The rats in control groups (n:6) were fed during the study without doing any application. The rats in testosteronegroup (n:7) were supplied with a $10 \mathrm{mg} / \mathrm{kg}$ dose of testosterone 5 days a week for 3 weeks. The rats in exercise group (n:7) did freestyle swimming exercise for 30 minutes a day for 5 days a weekfor 3 weeks. The rats in testosterone + exercise group (n:7) did freestyle swimming exercise for 30 minutes and were administered with $10 \mathrm{mg} / \mathrm{kg}$ dose of testosterone supplement for 5 days a week for 3 weeks. At the end of the trial, necessary biochemical parameters were measured in serums obtained by drawing blood from tails of the rats. While levels of Serum, LDH, CK-MB, and CKwere studied by using an autoanalyzer, Troponin I level was analyzed by using ELISA kit. SPSS 15.0 packaged software was usedin statistical evaluation of the data and the results were given as mean \pm SE. Since the data were convenient with the normal distribution, ANOVA test was applied for betweengroups comparison and Duncan test was used to identify from which group the difference was resulted. When between-groups values of troponin I, ck-MB, and LDH, which are indicators of heart damage, and enzyme CK, which is an indicator of muscle damage,for control, exercise, testosterone, and testosterone+exercise groups were compared, a statistically significant difference was determined between control, exercise, testosterone, and testosterone+exercise groups ( $\mathrm{p}<0.05)$. As a result of statistically analysis performed on all groups, the difference was found to be caused by testosterone and testosterone+exercise groups. Because testosterone production is naturally increased in the body during the exercise, swimming exercise and testosterone administration led to significant occurrence of troponin I, ck-MB, LDH, which are heart damage indicators in rats, and CK value, which is an indicator of muscle damage, in the blood.
\end{abstract}

Keywords:, Heart, Muscle Damage, Swimming Exercise, Testosterone

\section{INTRODUCTION}

AASs have been used by athletes for many years to increase strength, speed and durability. Although its effect seems to be positive at first, it is known that it has many physiological effects in human body (4). Because of the great effect on the body's muscle structure, testosterone is used to increase muscle performance in athletes (testosterone or synthetic androgen instead of testosterone) (6,7). Because AASs provide hypertrophy $(10,11)$ to increase muscle mass by athletes because of its provision of hypertrophy (16), it is physically good in young people that the recovery period is fast $(2,3,15,16)$.

It has profound effects on the human body of the hormones secreted by the endocrine system.
Therefore, it is known that any change in the endocrine system may affect the blood level and also affect human metabolism (32).

The hormone that determines gender-specific attitudes and behaviors in humans, especially in men, is testosterone. Testosterone is a hormone that easily passes the blood brain barrier with a steroid structure produced by cholesterol (1). Testosterone is more present in the body than other androgenic hormones. However, most testosterone is converted to dihydrotestosterone, which is more active in target tissues (21). Testosterone and dihydrotestosterone are all steroid compounds. Testosterone is the hormone, which is generally responsible for the formation of a distinct male sex character of the human body. In the life of the fetal 
life, the testes are stimulated with the presence of the gingival gonadropins in the placenta and secrete moderate testosterone. This hormone is present in the body during the fetal development period and even 10 or more weeks after birth. Therefore, testosterone is not produced until the age of 10-13 years. Then, testosterone production increases rapidly with the stimulation of anterior pituitary gonadotropic hormones during puberty (29).

When side effects of AAS were examined, it was stated that it causes sudden heart attack in the cardiovascular system, cerebrovascular diseases in the brain and nervous system, disrupting the function of the liver, causing hepatitis, increasing the risk of cancer and in the blood LDL and HDL (17). Another side effects of AAS are gender. Longterm use of steroids causes women to exhibit masculine behavior, excessive hair formation in certain regions, thickening of the vocal cords, deformity of the breasts, irregularity in the period and hair loss. In males, it is known that testosterone level may cause decrease in sperm quality and number and abnormal reduction in testes (33). In addition, it can affect the formation of pregnancy by increasing the internal structure of the uterus in the womb and causing an abnormal expansion of the testosterone intake (8).

The aim of this study was to investigate the effect of testosterone supplementation on heart and muscle damage in swimming rats.

\section{MATERIALS \& METHODS}

The study was performed on 27 rats (Wistar, male), 30 days from Selcuk University Experimental Medicine Research and Application Center. The study was approved by the Ethics Committee of the Center for Experimental Research and Application at Selcuk University (number of decisions: 2016-29). Rats were fed and housed in the experimental animal unit, plastic rat cages, $23 \pm 2{ }^{\circ} \mathrm{C}$ at room temperature, $50 \pm 10 \%$ humid environment, $12 / 12$ day / night light period, ad-libitum. The rats were provided with daily fresh water $(\sim 50 \mathrm{ml} /$ day / rat) that they could drink at any time. Animals were divided into 4 groups as follows.

1. Group: C (Control group, n: 6), Standard rat feed and drinking water ad libitum were given during the study period.
2. Group T (Testosterone group, n: 7), Standard rat feed and drinking water ad libitum were given during the study period. Testosterone (sustanon) was administered at a dose of $10 \mathrm{mg} / \mathrm{kg} / \mathrm{rat}$ diluted $100 \mathrm{ml}$ in peanut oil and administered intraperitoneally for 5 days and 3 weeks.

3. Group: E (Exercise group, n: 7), Standard rat feeding and drinking water ad libitum were given during the study period. The rats in this group were given swimming training for 3 weeks and 5 days a week for 30 minutes.

4. Group: TE (Testosterone + Exercise group, $\mathrm{n}$ : 7), Standard rat feed and drinking water ad libitum were given during the study period. Testosterone (sustanon) was administered to this group by intraperitoneal injection at a dose of $10 \mathrm{mg} / \mathrm{kg}$ for 5 days per week and was included in the exercise program 1 hour before the start of the exercise.

The rats in all groups, including the control group, were weighed by weighing with a precision scale (Ohaus CS 200 Compact scala, Mexico) once a week for the duration of the experiment and before the experiment, and the mean weight was measured weekly. The required dose adjustment was carried out weekly in terms of the live weight of the rats belonging to testosterone treated groups.

Exercise Program: Swimming exercises were performed in swimming pool for 3 weeks, 5 days 30 min. The water tank was filled with water with a temperature of $25^{\circ} \mathrm{C}$ and rested for 1 hour and the water temperature was $22-25{ }^{\circ} \mathrm{C}$. For adaptation to water at the start of exercise, the rats were kept free in water for 10 minutes and then a swimming exercise program was applied. At the end of the exercise time, the rats were removed from the water tank and dried with a towel.

Measurements and Analysis: At the end of the experiment, the necessary biochemical parameters were obtained from the sera of the rats. Serum, LDH, CK-MB, CK levels were determined in autoanalyser (Ilab 300 Plus, Milan, Italy) and Troponin I levels were determined by ELIZA kit.

Statistical Analysis: Statistical data were analyzed using SPSS 15.0 (SPSS 15.0 for Windows / SPSS ${ }^{\circledR}$ Inc., Chicago, USA). ANOVA and Duncan test were used to compare data between groups. 


\section{RESULTS}

Table 1. The levels of control (c), exercise (E), testosterone (T) and testosterone + exercise (TE) were compared with blood troponin I, creatinine kinase (ck), ck-MB and LDH values. (Mean $\pm \mathrm{SE}$ )

\begin{tabular}{lllll}
\hline Groups & $\begin{array}{l}\text { Troponin I } \\
(\mathbf{n g} / \mathbf{m L})\end{array}$ & $\begin{array}{l}\text { ck-MB } \\
\mathbf{( n g / m L}\end{array}$ & $\begin{array}{l}\text { LDH } \\
(\mathbf{m g} / \mathbf{d L})\end{array}$ & $\begin{array}{c}\text { Creatine Kinase (ck) } \\
\mathbf{( U / L )}\end{array}$ \\
\hline Control & $13.25 \pm 6.71^{\mathrm{b}}$ & $342.68 \pm 105.46^{\mathrm{c}}$ & $277.16 \pm 76.28^{\mathrm{bc}}$ & $266.50 \pm 40.61^{\mathrm{b}}$ \\
\hline Exercise & $10.88 \pm 1.53^{\mathrm{b}}$ & $280.33 \pm 32.36^{\mathrm{c}}$ & $170.33 \pm 40.56^{\mathrm{c}}$ & $184.50 \pm 18.98^{\mathrm{b}}$ \\
\hline Testosterone & $16.17 \pm 2.64^{\mathrm{b}}$ & $616.66 \pm 105.59^{\mathrm{b}}$ & $648.16 \pm 132.70^{\mathrm{b}}$ & $401.33 \pm 102.15^{\mathrm{ab}}$ \\
\hline Tes+Exercise & $34.32 \pm 7.50^{\mathrm{a}}$ & $954.16 \pm 45.03^{\mathrm{a}}$ & $1078.16 \pm 198.60^{\mathrm{a}}$ & $590.33 \pm 115.02^{\mathrm{a}}$ \\
\hline \multicolumn{4}{l}{ Different letters in the same column $(\mathrm{a}, \mathrm{b}, \mathrm{c})$ are statistically significant $($ Duncan test, $\mathrm{p}<0.05)}$. \\
\hline
\end{tabular}

When $\mathrm{C}, \mathrm{E}, \mathrm{T}$ and $\mathrm{TE}$ groups were compared between the groups. the values of troponin I protein were determined as C $(13.25 \pm 6.71 \mathrm{ng} / \mathrm{mL})$, E $(10.88$ $\pm 1.53 \mathrm{ng} / \mathrm{mL}), \mathrm{T}(16.17 \pm 2.64 \mathrm{ng} / \mathrm{mL})$ and TE $(34.32$ $\pm 7.50 \mathrm{ng} / \mathrm{mL}$ ) were found to be statistically significant differences $(p<0.05)$. Post hoc test was used to determine which group the difference was caused and it was seen that the difference was caused by TE group.

When the values of $\mathrm{C}, \mathrm{E}, \mathrm{T}$ and TE groups of creatine kinase-MB (ck-MB) were compared in the determination of heart injury. C (342.68 \pm 105.46 $\mathrm{ng} / \mathrm{mL}), \mathrm{E}(170.33 \pm 40.56 \mathrm{ng} / \mathrm{mL}), \mathrm{T}(616.66 \pm 105.59$ $\mathrm{ng} / \mathrm{mL})$ and TE $(954.16 \pm 45.03 \mathrm{ng} / \mathrm{mL})$ groups were found to be statistically significant $(p<0.05)$. Post hoc test was used to determine which groups caused the difference and it was seen that the difference was caused by $\mathrm{T}$ and TE groups.

When we compared the values of $\mathrm{C}, \mathrm{E}, \mathrm{T}$ and $\mathrm{TE}$ groups of LDH enzyme in determination of heart damage. C $(277.16 \pm 76.28 \mathrm{mg} / \mathrm{dL})$, E $(170.33 \pm 40.56$ $\mathrm{mg} / \mathrm{dL}), \mathrm{T}(648.16 \pm 132.70 \mathrm{mg} / \mathrm{dL})$ and TE $(1078.16 \pm$ $198.60 \mathrm{mg} / \mathrm{dL}$ ) were found to be statistically significant differences $(p<0.05)$. Post hoc test was used to determine which groups caused the difference and it was seen that the difference was caused by $\mathrm{T}$ and TE groups.

When the values of $\mathrm{C}$. E. T and TE groups were compared between C, E, T and TE groups. C (266.50 $\pm 40.61 \mathrm{U} / \mathrm{L})$, E $(184.50 \pm 18.98 \mathrm{U} / \mathrm{L}), \mathrm{T}(648.16 \pm$ $132.70 \mathrm{U} / \mathrm{L})$ and TE $(401.33 \pm 102.15 \mathrm{U} / \mathrm{L})$ groups were found to be statistically significant differences $(p<0.05)$. Post hoc test was used to determine which groups caused the difference and it was seen that the difference was caused by $\mathrm{T}$ and TE groups.

\section{DISCUSSION}

Anabolic androgenic steroids have many side effects in both young and adults (22). Nandrolone Decanoate application of the effects of the application of Nandrolone Decanoate on the heart muscle was investigated in rats. It was reported that the use of Nandrolone Decanoate had negative effects on the heart muscle and could negatively affect the benefits of exercise (14).

Troponin I protein is an important protein in the determination of heart damage in the body (5). During exercise, the body naturally increases testosterone production. In some studies, uncontrolled exercise can also reduce testosterone production. Exercises that are appropriate and specific at the rhythm can provide better production and functioning of the testosterone hormone secreted by the body. On the contrary, it is stated that overdose cardio exercise may decrease the testosterone level $(12,18)$. When testosterone supplementation is taken with the level of tetstosterone increased by exercise, it causes more harm than good in the body (16). The most important of these is the Troponin I protein, which has a high blood value in heart failure (25). In the study, which investigated the effects of AAS use on swimming-exercised rats, it was reported that the use of AAS impaired cardiac hypertrophy and adversely affected the benefits of aerobic exercise (26).

The creatine kinase-MB (CK-MB) enzyme is an enzyme found in skeletal muscle, brain, heart and other organs in the human body (9). When CK-MB enzyme rises in the blood, it can cause heart attack. The enzyme used as a marker of heart damage is secreted from the damaged cell and then mixed with the blood to increase the level of CK-MB in the blood. (27). Exercise can automatically increase the CK-MB level in the blood. Therefore, careful planning of exercise programs is necessary. When testosterone is supplemented with exercise, the CKMB level rises rapidly in the blood in a short time (34). In the present study, CK-MB enzyme was higher in Tve TE groups than the other groups. In addition, the value of the enzyme was measured at the highest level in the group where the swimming exercise and testosterone supplement were 
administered. CK-MB enzyme can be a significant marker of heart damage when taken with exercise and testosterone supplementation similar to the effect of Troponin I protein.

Another important marker of heart damage is the LDH enzyme. LDH is an enzyme necessary for use in the production of energy normally used. It is found in all the body cells. In case of any damage, the level of the blood rises rapidly (20). Troponin I, CK-MB and LDH enzymes should be considered together to determine heart damage (3). During heart attack, LDH enzyme increases in blood. In severe and compelling exercises, it may cause elevated levels of LDH in the blood (34). In the present study, the LDH enzyme in the T and TE groups given testosterone was higher in blood than $\mathrm{E}$ and $\mathrm{K}$ groups. The highest number of heart damage occurred in the TE group, who received both testosterone and swimming exercises. From this finding of the study, it can be concluded that the testosterone hormone is more harmful to the body when used with exercise. Taşgin et al (30) in their study of testosterone and nandrolone combined with the increase in LDH level and the difference was reported to be statistically significant.

Muscle damage markers as blood viewed creatine kinase $(\mathrm{CK})$ enzyme derived from creatine is necessary for muscle contraction and body is an enzyme used to produce energy quickly (Kanda et al 2013). In the event of any damage, muscle cells may cause CK to be mixed. Elevated CK levels may be a marker of muscle damage (3). A high level of CK in the blood may be a sign of muscle damage. A person exercising regularly may experience less muscle damage than a person starting a new exercise. While severe exercises lead to significant increases in CK level, the increase in lighter exercises is not so much (19). In the present study, testosterone given T and TE groups showed higher levels of CK enzyme in the blood than exercise and control groups. The highest muscle damage was seen in the TE group, who received both testosterone and swimming exercises. From this finding of the study, it can be concluded that the testosterone hormone is more harmful to the body when used with exercise. In the study of Taşgin et al (30), testosterone and nandrolone were reported to be elevated in CK level and the difference was statistically significant.

\section{CONCLUSIONS}

In the study conducted to investigate the effect of testosterone supplementation on heart and muscle damage in swimming rats. It is seen that young people tend to use banned substances in order to improve their physical appearance and to gain more performance in competitions by increasing their muscle mass and strength. In general, when the use of prohibited substances raises many problems in the organism and all the negative results of this study are taken into consideration; It can be said that it causes mainly heart and muscle damage in the body and these results can make a significant contribution to the awareness of athletes.

\section{ACKNOWLEDGEMENTS}

This study is a portion of master thesis and is supported by Selcuk University Scientific Research Projects Coordinator (SUBAPK, 16202029).

\section{REFERENCES}

1. Alhuzaim, O. N., Lewis, E. J., Lovblom, L. E., Cardinez, M., Scarr, D., Boulet, G., Brent, M. H. (2018). Bone mineral density in patients with longstanding type 1 diabetes: Results from the Canadian study of longevity in type diabetes. Journal of Diabetes and its Complications.

2. Barkhe MS, Yesalis CE. Abuse of anabolic androgenic steroids and related substances in sport and exercise. Current Opinion in Pharmacology, $2004: 4,614-20$.

3. Bieuzen, F., Brisswalter, J., Easthope, C., Vercruyssen, F., Bernard, T., \& Hausswirth, C. (2014). Effect of wearing compression stockings on recovery after mild exerciseinduced muscle damage. International journal of sports physiology and performance, 9(2), 256-264.

4. Borges T, Eisele G, Byrd C, 2001. Rewiev of androgenic anabolic steroid use. Office of Safeguards and Security U.S. Department of Energy, 1-18.

5. Borlak J, Thum T, 2003. Hallmarks of ion channel gene expression in end-stage heart failure. The FASEB Journal, 17(12), 1592-608.

6. Buskens V, Raub W, Van Miltenburg N, Montoya ER, Van Honk J, 2016. Testosterone Administration Moderates Effect of Social Environment on Trust in Women Depending on Second-to-Fourth Digit Ratio. Scientific reports, 6:45-51.

7. Carrier N, Saland SK, Duclot F, He H, Mercer R, Kabbaj M. The anxiolytic andantidepressant like effects of testosterone and estrogen in gonadectomized male rats. Biological psychiatry, 2015; 78(4), 259-69.

8. Casavant MJ, Blake K, Pharmd JG, Yates A, Copley LM. Consequences of use of anabolic androgenic steroids. Pediatr Clin N Am, 2007; 54, 677-90.

9. Chon H, Lee S, Yoon SY, Lee EK, Chang SI, Choo J, 2014 SERS-based competitive immunoassay of troponin I and CK- 
MB markers for early diagnosis of acute myocardial infarction. Chemical Communications, 50(9), 1058-60.

10. Comeglio P, Cellai I, Filippi S, Corno C, Corcetto F, Morelli A, Maggi M. Differential Effects of Testosterone and Estradiol on Clitoral Function: An Experimental Study in Rats. The Journal of Sexual Medicine, 2016: 13(12), 1858-71.

11. Fontana K Campos GER, Staron RS, Cruz-Höfling MA, Effects of Anabolik Steroids and High-Intensity Aerobic Exercise on Skeletal Muscle of Transgenic Mice. PLoS One, 2013: 8(11), 1-8.

12. Gomes MJ, Martinez PF, Pagan LU, Damatto RL, Cezar MD, Lima AR, Okoshi MP, 2017. Skeletal muscle aging: Influence of oxidative stress and physical exercise. Oncotarget, 5 .

13. Harmer PA. Anabolic-androgenic steroid use among young male and female athletes: is the game to blame. Br J Sports Med, 2010: 44, 26-31.

14. Hassan AF, Kamal MM. Effect of exercise training and anabolic androgenic steroids on hemodynamics, glycogen content, angiogenesis and apoptosis of cardiac muscle in adult male rats. Int J Health Sci, 2013: 7(1), 47-60.

15. Hoffman JR, Ratamess NA. Medical issues associated with anabolic steroid use: are they exaggerated. Journal of Sports Science and Medicine, 2006: 5, 183-93.

16. Kerr JM, Congeni JA . Anabolic-androgenic steroids: use and abuse in pediatric patients. Pediatr Clin N Am, 2007: 54, 777185.

17. Kicman AT. Pharmacology of anabolic steroids.British Journal of Pharmacology, 2008: 154, 502-21.

18. Knebel F, Spethmann S, Schattke S, Dreger H, Schroeckh S, Schimke I, Lock J, 2014. Exercise-induced changes of left ventricular diastolic function in postmenopausal amateur marathon runners: assessment by echocardiography and cardiac biomarkers. European journal of preventive cardiology, 21(6), 782-90.

19. Koch, A. J., Pereira, R., \& Machado, M. (2014). The creatine kinase response to resistance exercise. J Musculoskelet Neuronal Interact, 14(1), 68-77.

20. Leal-Junior ECP, Vanin AA, Miranda EF, de Carvalho PDTC, Dal Corso, S., \& Bjordal, J. M. (2015). Effect of phototherapy (low-level laser therapy and light-emitting diode therapy) on exercise performance and markers of exercise recovery: a systematic review with meta-analysis. Lasers in medical science, 30(2), 925-939.

21. Lindsay, H. A., Srinivas, C., \& Ouzounian, M. (2019). Open Thoracoabdominal Aortic Aneurysm Repair. In Principles and Practice of Anesthesia for Thoracic Surgery (pp. 675-695). Springer, Cham.

22. Maravelias C, Dona A, Stefanidou M, Spiliopoulou C. Adverse effects of anabolic steroids in athletes: A constant threat. Toxicol Lett, 2005: 158, 167-75.
23. Naraghi MA, Abolhasani F, Kashani I, Anarkooli IJ, Hemadi M, Azami A, Barbarestani M, Aitken RJ, Shokri S. The effects of swimming exercise and supraphysiological doses of nandrolone decanoate on the testis in adult male rats: a transmission electron microscope study. Folia Morphol, 2010: 69 (3), 138-46.

24. Papazisis G, Kouvelas D, Mastrogianni A, Karastergiou A. Anabolic androgenic steroid abuse and mood disorder. A case report Int J Neuropsychopharmacol, 2007: 10(2), 292-293.

25. Pesonen E, Pussinen P, Huhtaniemi I, 2016. Adaptation to acute coronary syndrome-induced stress with lowering of testosterone: a possible survival factor. European Journal of Endocrinology, 174(4), 481-89.

26. Rocha FL, Carmo EC, Roque FR, Hashimoto NY, Rossoni LV, Frimm C, Ane'as I, Negra'o CE, Krieger JE, Oliveira EM. Anabolic steroids induce cardiac renin-angiotens in system and impair the beneficial effects of aerobic training in rats. Am J Physiol Heart Circ Physiol, 2007: 293(6), 3575-83.

27. Safdar B, Bezek, SK, Sinusas AJ, Russell RR, Klein MR, Dziura JD, D'onofrio G, 2014. Elevated CK-MB with a normal troponin does not predict 30-day adverse cardiac events in emergency department chest pain observation unit patients. Critical pathways in cardiology, 13(1), 14-9.

28. Shokri S, Hemadi M, Bayat G, Bahmanzadeh M, JafariAnarkooli I, Mashkani B. Combination of running exercise and high dose of anabolic androgenic steroid, nandrolone decanoate, increasesprotamine deficiency and DNA damage in rat spermatozoa. Andrologia, 2014: 46(2), 184-90.

29. Solís-S, J. C., García-Solís, P., Robles-Osorio, L., \& Luis, H. (2018). Beneficial Effects of Phytochemicals on the Endocrine System. Fruit and Vegetable Phytochemicals: Chemistry and Human Health...., 2, 67.

30. Tasgin E, 2013. The effect of nandrolone decanoate on the concentrations of IL1- $\beta$, TNF- $\alpha$, IL- 4 , IL- 6 and biocheminal parameters in male and female rats. Selcuk University Health Sciences Institute, Phd Thesis, 36-42.

31. Tasgin, E., Lok, S., \& Demir, N. (2011). Combined usage of testosterone and nandrolone may cause heart damag. African Journal of Biotechnology, 10(19), 3766-3768.

32. Wood RI, Armstrong A, Fridkin V, Shah V, Najafi A, Jakowec M, 2013. 'Roid rage in rats? Testosterone effects on aggressive motivation, impulsivity and tyrosine hydroxylase. Physiology \& behavior, 110, 6-12.

33. Yavari A. Abuse of anabolic androgenic steroids. Journal of Stress Physiology \& Biochemistry, 2009: 5(3), 22-32.

34. Zhao Z, Cao X, 2016. GW27-e1050 Cardioprotective effect of exercise preconditioning in military personnel during high intensity training. Journal of the American College of Cardiology, 68(16), C76. 